PERM JOURNAL OF PETROLEUM AND MINING ENGINEERING ВЕСТНИК ПНИПУ. ГЕОЛОГИЯ. НЕФТЕГАЗОВОЕ И ГОРНОЕ ДЕЈО

ISSN 2224-9923

Volume / Tom 17 №1 2018

http://vestnik.pstu.ru/geo/

УДК 622.411.52:544.77

Article / Статья

(C) PNRPU / ПНИПУ, 2018

\title{
METHODOLOGICAL BASES OF STUDYING THE DISPERSION COMPOSITION OF MINE COAL DUST
}

\section{Vladimir A. Rodionov}

Saint Petersburg University of State Fire Service of EMERCOM of Russia (149 Moskovskiy av., Saint Petersburg, 199105, Russian Federation)

\section{МЕТОДОЛОГИЧЕСКИЕ ОСНОВЫ ИЗУЧЕНИЯ ДИСПЕРСИОННОГО СОСТАВА ШАХТНОЙ КАМЕННОУГОЛЬНОЙ ПЫЛИ}

\section{В.А. Родионов}

Санкт-Петербургский университет государственной противопожарной службы МЧС РФ

(196105, Россия, г. Санкт-Петербург, Московский пр., 149)

Received / Получена: 27.12.2017. Accepted / Принята: 02.02.2018. Published / Опубликована: 30.03.2018

Key words:

coal dust, scanning electron microscopy, dust dispersion, optical microscopy, laser diffraction analysis, sieve granulometric analysis, mine dust, self-dispersing of coal dust.
Ключевые слова:

угольная пыль, растровая электронная микроскопия, дисперсность пыли, оптическая микроскопия, лазерный дифракционный анализ, ситовой гранулометрический анализ, шахтная пыль, самодиспергация угольной пыли.
The methodology of investigating the dispersion composition of mine dust is presented. The methodology is based on modern science-intensive methods such as the method of scanning microscopy and simple methods such as the method of sieve granulometric analysis. Today, the granulometric analysis is given great attention aimed to study the dimensions and aerodynamic characteristics of mine dust particles. The methods are applied separately from each other. Therefore, the paper discusses the most popular science methods gives recommendations on their joint application on the basis of the author's research on the dispersion composition of mine dust. Methods of scanning ectronic and optical microscopy are briefly described. Laser diffraction and sieve granulometric analyzes used to study the composition of coal mine dust are considered. That is chosen to use mine coal dust collected from the surface of hydraulic support racks of cleaning faces and coal dust obtained by the method of forced grinding of hard coal samples of different grades and anthracite as the samples for study. Samples of coal are taken from the working space of the mines of the Pechora, Kuznetsk and Donbass coal basins.

Based on a comprehensive study of methods and analysis of results of studying the dispersion composition, their main advantages and disadvantages are given.

The research methodology is based on physical methods for studying the dispersion characteristics of mine dust. In connection with the fact that one or another method is implemented in one device (installation), then in order to obtain complex data it is proposed to combine them into knowledge-intensive pairs.

The combination in pairs of the equipment allows to study thoroughly both the dispersion composition and morphology of the dust particles, including the surface structure of dust particles if such a task is posed. Selection of samples and processes of preparing samples for research are in the basis of all methods used for obtaining qualitative and reliable scientific results. As a result of the experimental work carried out to prevent endogenous fires and explosions in the coal mine area, the author proposes to use a comprehensive approach consisting in applying synchronous thermal analysis methods together with methods for studying the dispersion composition of coal dust.

Приведена методология исследования дисперсионного состава шахтной пыли, в основе которой лежат как современные наукоемкие методы, например метод растровой микроскопии, так и наиболее простые методы, например метод ситового гранулометрического анализа. В настоящее время гранулометрическому анализу уделяется большое внимание, направленное на изучение размеров и аэродинамических характеристик частиц шахтной пыли, причем методы применяются раздельно друг от друга. Поэтому в настоящей статье рассмотрены наиболее востребованные наукой методы и даны рекомендации по их совместному применению на основе полученных автором работ по изучению дисперсионного состава шахтной пыли. Кратко описаны методы растровой электронной и оптической микроскопии, рассмотрен лазерный дифракционный и ситовой гранулометрический анализы, применяемые для изучения состава каменноугольной шахтной пыли. Образцами для исследований выбрана шахтная угольная пыль, отобранная с поверхности стоек гидравлической крепи очистных забоев, а также угольная пыль, полученная методом принудительного размола образцов каменного угля различных марок и антрацита. Образцы каменного угля отобраны из рабочего пространства лавы шахт Печорского, Кузнецкого и Донбасского угольных бассейнов.

На основании комплексного всестороннего исследования методик и анализа результатов изучения дисперсионного состава приведены их основные достоинства и недостатки.

Методология исследования основана на физических методах изучения дисперсионных характеристик шахтной пыли. В связи с тем что тот или иной метод реализован в одном приборе (установке), то для получения комплексных данных предложено их объединить в наукоемкие пары.

Сочетание в парах указанного оборудования позволит всесторонне изучить не только дисперсионный состав, но и морфологию частиц пыли, в том числе, если будет поставлена такая задача, и структуру поверхности частиц пыли. В основе всех методов для получения качественных и достоверных научных результатов лежат отбор пробы и процессы подготовки образцов для исследования.

В результате проведённых экспериментальных работ для профилактики и предотвращения эндогенных пожаров и взрывов в пространстве угольных шахт автор предлагает применить комплексный подход, заключающийся в применении методов синхронного термического анализа совместно с методами изучения дисперсионного состава угольной пыли.

Vladimir A. Rodionov - Doctoral student at the Faculty of the Highest Qualification Personnel Training (mob. tel.: +007 921 325 83 97, e-mail: 79213258397@mail.ru).

Родионов Владимир Алексеевич - докторант факультета подготовки кадров высшей квалификации (моб. тел.: +007921 325 83 97, e-mail: $79213258397 @$ @аil.ru). 


\section{Introduction}

An analysis of modern studies in the field of industrial safety showed that emergencies in Russian mining (primarily in coal mines), continue to occupy the main place among the most dangerous phenomena in underground mining $[1$, 2]. In addition, despite the existing and developed in the industry regulatory and technical measures to improve the safety of production, emergencies related to the death of miners and suspension/termination of the operation of mines occur every five years. Dynamics show that the number of large accidents compared to the previous decade has increased twice [3-8].

In order to prevent emergencies in the industry, a number of coal companies are developing new standards dedicated to ensure the safety. There is an example of Siberian Coal Energy Company JSC who developed the "Charter of Combat with Hazardous Industrial Situations" [9]. However, in case of constant development of mining equipment to increase its productivity, mining and roadheading of deeper seams and as a result, geological and mining conditions that changes for the worse, taking actions are insufficient. In our opinion, due to the growing pressure on the face and increasing depth of production, there is an increase in accidents for such dangerous factors as methane and coal dust. The contribution of methane and coal dust to the emergencies can not be ignored. It is necessary to study some times the physical, chemical and explosive-fire hazard properties of both hybrid methane-coal mixtures and coal dust. We believe that due to explosive and fire hazard properties of coal and coal dust that constantly change (especially while mining down to underlying horizons) they should be given by special attention. In addition, a dispersion composition change of mine dust can lead to the risk of safety of respiratory organs of miners by traditional means of protection. The facts mentioned are confirmed in the papars [10-14]. In addition, it was established in [15] that coal dust tends to self-disperse. It is also established that changes in dust dispersion composition toward decreasing particle size plays an important role in the autocatalytic spontaneous combustion which can lead to a fire or explosion of the methane-coal mixture.

Taking into account the above mentioned, we believe that in order to ensure the fire and explosion safety of production in general and coal mine in particular it is impossible not to use the methods of prevention and control of coal dust explosions based on the laws of chemical kinetics and thermodynamics and a number of other physical and chemical characteristics of mine dust. The assertion we made is based on the analysis of results of research given in $[1,9,11$, 12, 16-22]. It should be noted that the main efforts should be focused on a comprehensive study of chemical processes occurring both on the surface and inside each particle. That kind approach continues and deepens the research of mine dust, carried out by S.B. Romanchenko, who studied the dimensions and aerodynamic properties of dust aerosols. The main results are given in works [15, 23 and 24].

\section{Objective}

The purpose of the paper is to develop a methodology for studying the dispersion composition of coal dust taking into account the modern (innovative) achievements of science and technology that allow to study both the geometric, physical and chemical characteristics of dust particles in comples and reveal the most informative and effective express methods for its analysis. 


\section{Object of study}

The objects of the study were:

1) mine dust samples taken from the surface of hydraulic support rails of a longwall (according to recommendations [23]);

2) samples of coal from the Pechorskiy coal basin (Zh-type coal), Kuznetskiy coal basin (coal of $\mathrm{Zh}, \mathrm{G}$ and DG types) and Donetskiy coal basin (anthracite), taken from the longwal lspace;

3 ) dispersed coal samples of the types mentioned above.

\section{Methods and techniques of research}

The information given in [22-29] was considered in the research work. Taking into account the scientific and technical information given in references, the following methods for investigating the dispersion composition of mine dust were used:

1) method of scanning electron microscopy (SEM);

2) microscopic method of granulometric analysis;

3) sieve method of granulometric analysis;

4) laser diffraction analysis of dispersed materials.

A scanning electron microscope TESCAN (SEM) with an X-ray spectral analysis system was used in the study. Work on a SEM was guided by the technique of the equipment manufacturer and data stated in papers $[15,30]$.

Analysis of dust dispersion compositions was carried out using a LEICA DM 4000 series microscope. For visualization of different dust samples on dispersion appropriate techniques of work with the complex were used in accordance with recommendations (microscope LEICA DM $4000+$ information processing application software Image Scope Color), experience of other researchers was considered as well [15, 23, 24, 31-33].

Dispersion analysis of hard coal and coal mine dust was carried out using an AS 200 RETSCH screen analyzer and set of RETSCH sieves. For laser diffraction analysis, a Malvern Mastersizer 2000 diffraction analyzer was used according to the method described in the papers $[23,30$ и 33-39].

\section{Results and discussion}

Images of the studied coal dust samples obtained by scanning electron microscopy are given in Fig. 1-3. Results were visualized using a TESCAN VEGA microscope with an X-ray microanalysis system.

Application software allows processing received images in automatic mode in accordance with the tasks assigned by the operator. The X-ray spectral analysis system allows determining the chemical elements of the focusing zone. In our case, that option allowed finding the location of the silicon in the coal (inner space of region 1 in Fig. 1). We also found that visually distinguished white zones are inclusions and interlayers of silicon in the coal (see Fig. 1b), and the areas indicated by the arrows are rock dust (see Fig. $1 b$ zone 2).

The main feature of the research methodology is sampling and sample preparation, conducted by well-known standard methods, for example, sampling for analysis was performed by the quartization method.

Fig. 1 shows the particles of G-type coal, glued to a substrate fixed on working tables of a microscope. Smaller dust particles located on the sample surface are clearly visible even at increase in 20 times. Fig. $1 b$ shows a zoomed in 504 times fragment of the surface of one of the samples. A structure of the sample being studied is layered 

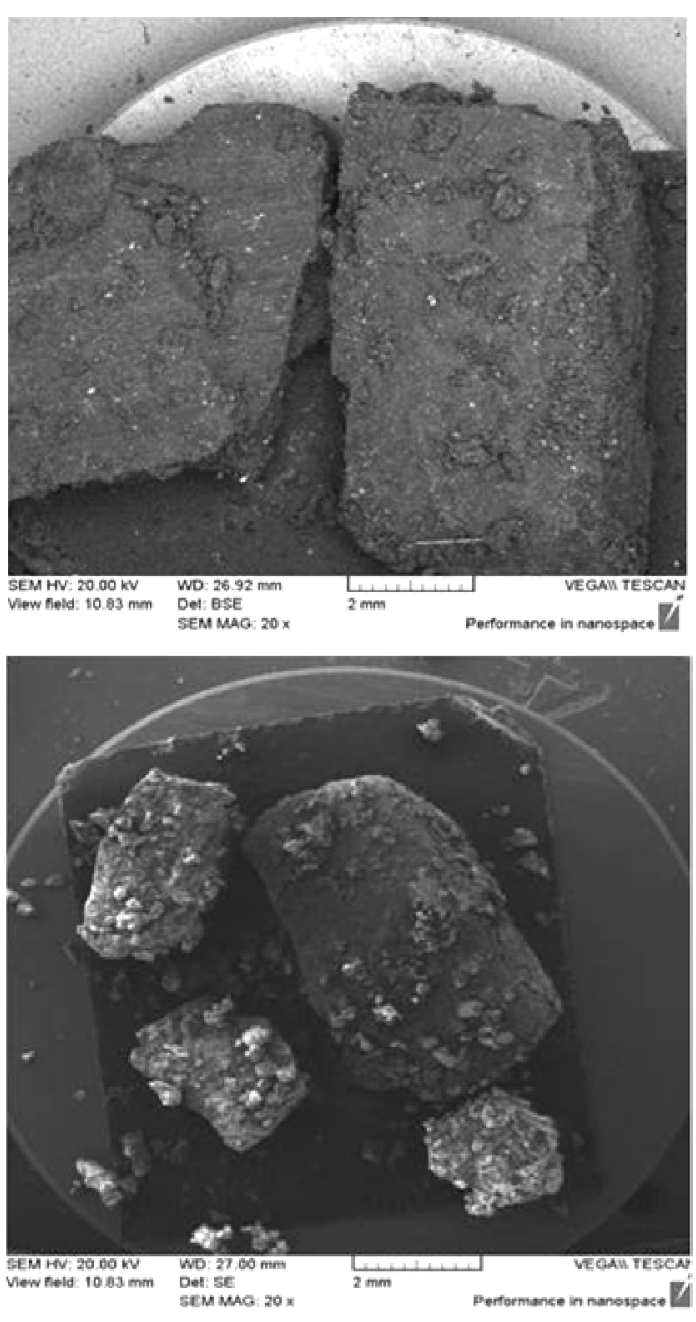

$a$

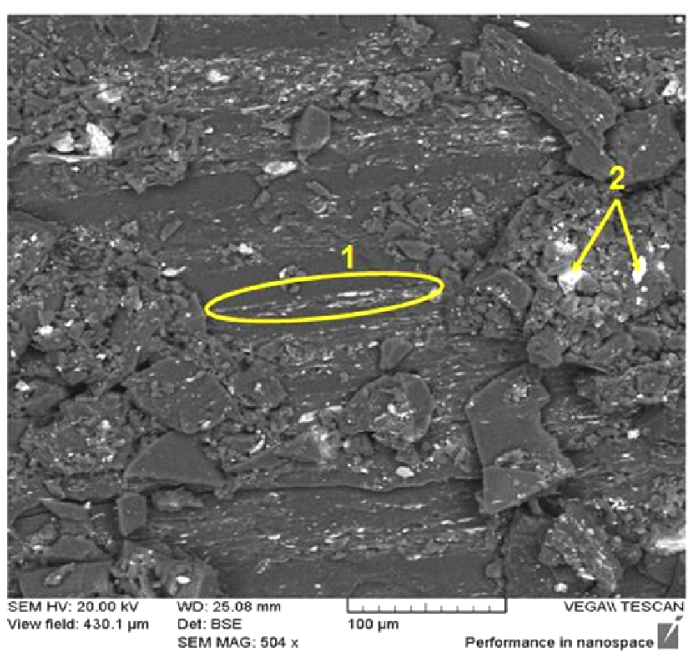

$b$

Fig. 1. Samples of coal with hard rock dust on the surface: $a$ - increase in 20 times; $b$ - the increased in 504-times area of one of the samples of Zh-type coal: in the selected area 1 - interlayer/impregnations of silicon; 2 - glowing particles - rock and heterogeneous. The zone 1 shows silicon interlayers, detected and established by X-ray diffraction analysis, and the light sections 2 indicated by the arrows are rock dust.

There are samples of rock dust particles zoomed in 1000 times visible in Fig. 2. Such a zoom is insufficient for analyzing the particle surface. It is clearly seen at 5000 times zoom that there is a crack passes through the surface of the particle. We can assume that, due to the presence of such cracks, the oxidation process can take place practically throughout the entire volume of the coal particle.

We believe that the processes of selfdispersion and all-round accelerating oxidation in conditions of unsatisfactory heat-exchange will ultimately lead to spontaneous combustion. It is confirmed by the authors of $[11-13,15,22-$ $24,32,38,39]$ that due to complexity of detailed study of physical and chemical processes leading to smoldering and self-ignition of mine dust it is important to study the coal dust particles by various methods.

It can be seen from visualization of dust samples given in Fig. 1-3 that zoom of 700 times is sufficient to study the appearance, structure and shape of particles.

Such a zoom helps to analyze the sample surface region interesting for us by elemetns, i.e. to determine the chemical element in the structure of the sample. Thus, the analysis of images, some of which are presented in the article, showed that the zoom of more than 700 times is necessary for a more detailed study of the structure and morphology of the sample. However, in order to create a representative (evidence) base, indicating a significant amount of dusty carbon-rock particles with a size of less than 5 microns, for example, as shown in Fig. 3, it is needed to zoom 


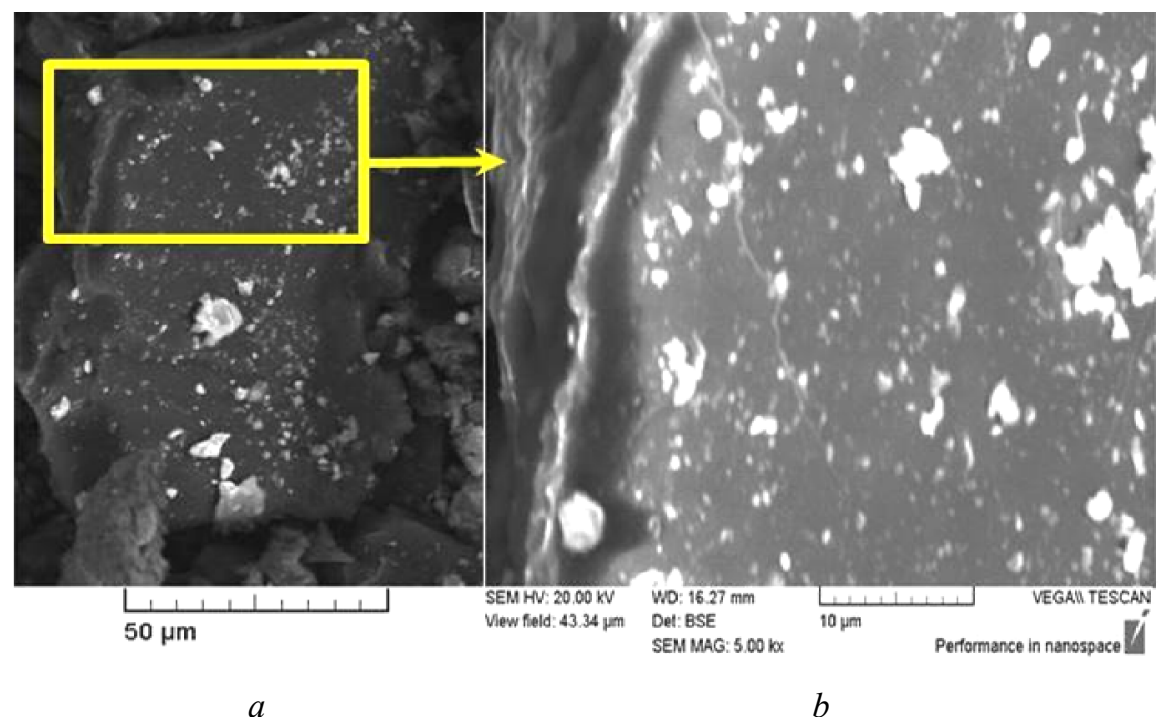

Fig. 2. Particles of coal dust with zoom of 1000 times $(a)$ and 5000 times $(b)$

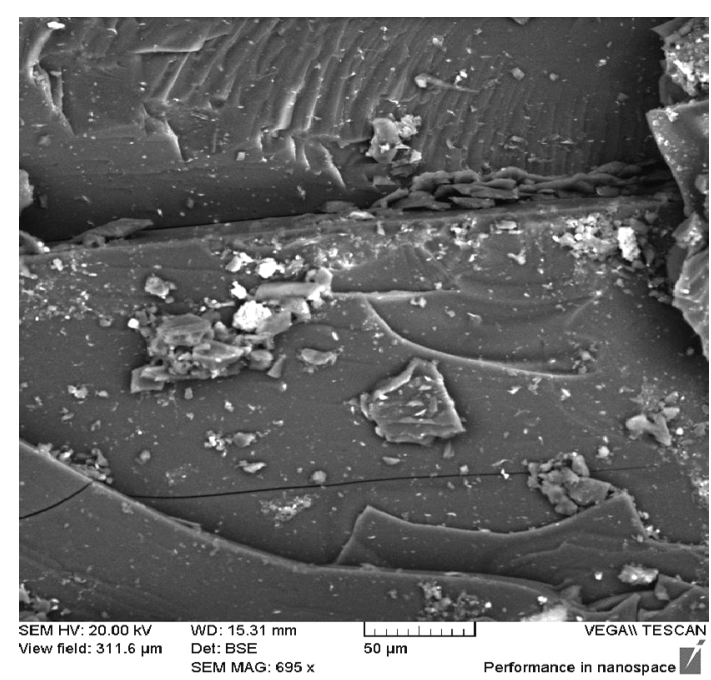

Fig. 3. Surface of a D-type coal sample zoomed in 695 times

in 1000 and 5000 times. The zoom of more than 5000 times is only necessary for studying the internal structure, i.e. study of the structure of dust particles and inclusions.

Based on our studies with scanning electron microscopy, the conclusions below can be drawn.

Advantages: the method is innovative and informative, meets almost all requirements to study both the dispersion composition of coal and hard coal particles and their morphology as well.
Disadvantages:

1) high cost of equipment and its maintenance are disadvantages of the method. The equipment exists only in large and/or advanced institutions of higher education, research institutes and laboratories;

2) high requirements for the qualification of personnel working on equipment;

3 ) in order to obtain qualitative results, it is necessary to carry out studies that require careful preparation of samples and strict adherence to the methods of operation at SEM.

Fulfillment of this condition is necessary to make any changes to an analysis process depending on the results obtained. Microscopic method for studying the granulometric composition of mine dust samples is an addition to the method of scanning electron microscopy only for the purposes of dispersion analysis.

Study of the dispersion composition of coal and mine dust was carried out on a LEICA DM 4000 microscope equipped with a digital camera. The images obtained were processed in the Image Scope Color application software. Some of the results obtained by us are shown in Fig. 4 and 6 . 
The figures show examples of the optical image of a microscope processed by software methods. Such a processing is necessary for statistical and geometric analysis of dust particles. An example of results of data processing is shown in Fig. 5.

A picture of coal dust particles taken from the hydraulic rack of the mechanical support of the mining section of the coal mine and processed in a special software, after which a particle size analysis was carried out is given below.

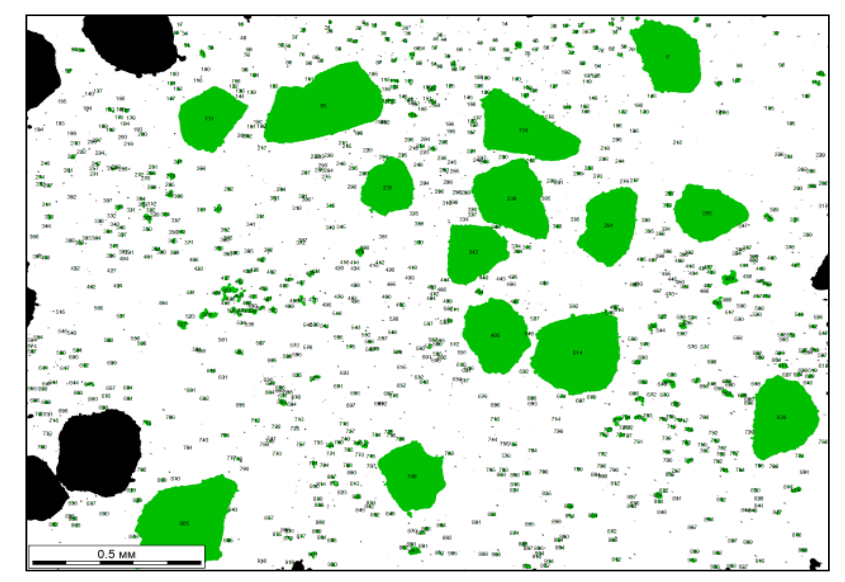

Fig. 4. Example of image analysis in the software Image

Scope Color (the picture shows a scale of $0.5 \mathrm{~mm}$ )

In this case Fig. 4 shows the intermediate result of the analysis of visible field image of the sample with fractional composition of 140-200 $\mu \mathrm{m}$. Despite the fact that during the sieve analysis static electricity was removed and sample of $100 \mathrm{~g}$ was taken, numerous dust particles much smaller in size than the particles of the studied fractional composition are observed on the photo.

The particles located at the image boundary and particles (see Fig. 4) in the lower left corner, which are in contact with them, were not subjected to analysis. In this case, when analyzing and comparing the image data with the image in the microscope eyepieces, it is possible to determine the separation of particles among themselves. The researcher can directly check in the eyepieces of the microscope and on the monitor screen whether the image is a particle conglomerate or single particle. The microscopic method of study is more labor-intensive in processing than other methods (SEM and laser diffraction analysis). The optical method of microscopic analysis should be applied, depending on specific problems, as the main or auxiliary method for studying mine dust particles. The result of software processing of a single shot of coal dust is given below as an example. Application software for the optical microscope LEICA DM 4000, Image Scope Color, allows to obtain complex characteristics of coal dust in the form of data presented in the table. Using the software complex, it is possible to measure not only the equivalent diameter, but also other geometric characteristics of the samples (length, width, area and others). The analysis of the data obtained is carried out in an automatic mode. In other words there was mathematical processing of the received data array performed. Results of determining the minimum and maximum particle size, dispersion and root-mean-square deviation are grouped to a table, an example of which is shown below (Fig. 5).

\begin{tabular}{|l|c|}
\hline \multicolumn{1}{|c|}{ Parameter measured } & Diameter of eq. \\
\hline Number of measurements & 869 \\
\hline Minimum value & $0.0228 \mathrm{~mm}$ \\
\hline Maximum value & $0.923 \mathrm{~mm}$ \\
\hline Average value & $0.0787 \mathrm{~mm}$ \\
\hline Dispersion & $0.00346 \mathrm{~mm}^{2}$ \\
\hline Mean-square deviations & $0.0588 \mathrm{~mm}$ \\
\hline
\end{tabular}

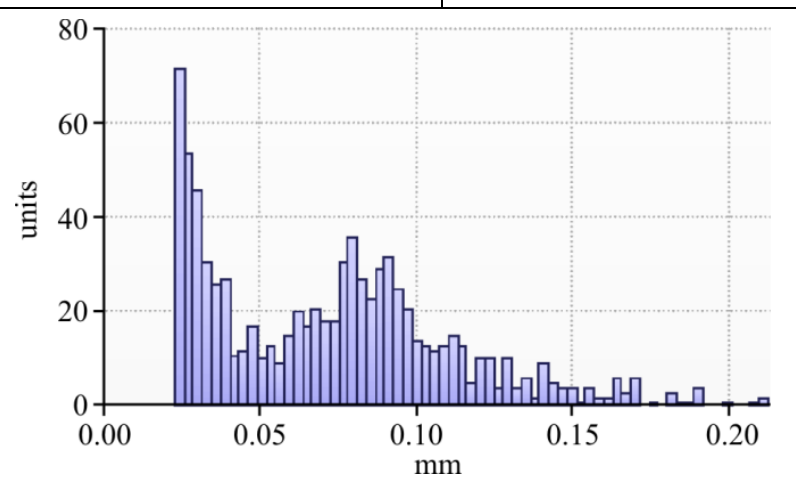

Fig. 5. Example of the variance report table 
In order to obtain reliable data, depending on the particle size, it is recommended to investigate at least 500 particles. A sufficient number is the number of particles equal to 2500 pieces [23, 26, $34,38]$. Results of the variance analysis for the same fraction, but with the calculation of a different number of particles are shown in Fig. 6.

On the basis of our studies performed with optical microscopy, the following conclusions can be drawn.

Advantages:

1) the method is sufficiently informative, meet almost all the needs for studying both the dispersion composition of coal and hard rock particles and their morphology. The advantages mentioned above are achieved by the presence of special lens allow to increase the particle in 50,100,200, 400 and 600 times; to study a particle in a different light; high-resolution digital video camera and capabilities of a specialized image processing software Image Scope Color;

2) availability of training in working with techniques on equipment and using software;

3) practical experience of studying dust particles showed that in some cases, in particular the comprehensive study of particles larger than $63 \mu \mathrm{m}$ (for Zh, GZh-types of coal of 100 microns),

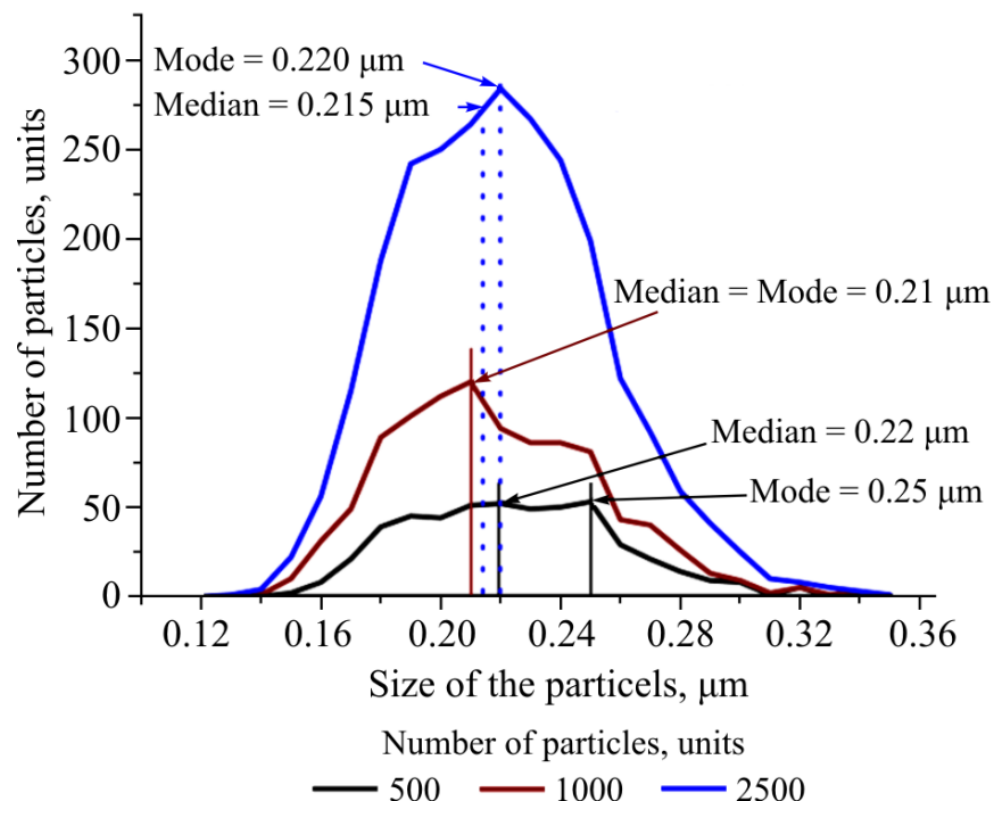

Fig. 6. Dynamics of change in the dispersion analysis as a function of number of particles

instead of using the microscope, a highresolution digital camera equipped with a macro lens can be implemented. Using the Image Scope Color for image processing software allow in some case to get even better results, than on a microscope. In addition to the optical microscope LEICA DM 4000, a digital camera Sony alfa-5000, macro lens Sony $30 \mathrm{~mm} \mathrm{f/3.5,}$ macro- and LED lighting Aputure Amaran AHL-N60 were applied by the autor during the study of coal dust particles. Besides, a digital microscope Digital Microscope with a 5-megapixel camera and 300-fold magnification was used above equipment mentioned to study fractions over 100 microns. 
Disadvantages:

1) existing limitations on the study of fractions less than $63 \mu \mathrm{m}$;

2) it takes time to get skills and work algorithm in order to get high-quality results;

3) a lot of labor, it is required to receive and process up to 2500 pieces of dust, for which it is necessary to make about 200 shots.

To our mine, third place for informativeness is taken by the sieve method of granulometric analysis. The method is somehow often used as a preparatory sample before the studies with use of electronic or optical microscopes.

In particular, using this method we managed to establish that for coal types of various deposits considered in this article fractions of less than $140 \mu \mathrm{m}$ account for more than $50 \%$ of the sieving mass. The main results are shown in Fig. 7.

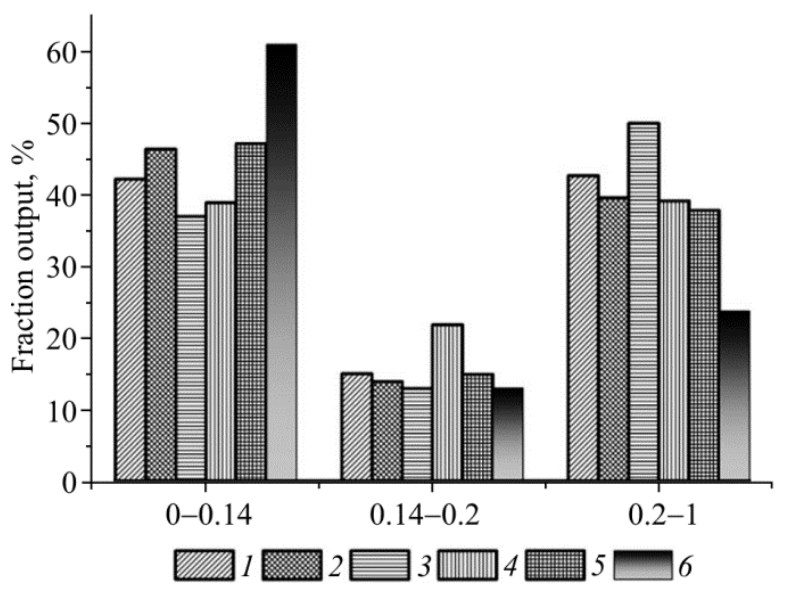

Fig. 7. Results of sieving granulometric analysis of coal dust with a dispersion of less than $1 \mu \mathrm{m}$

It can be seen from the data given in Fig. 7 that depending on the grindability of coal, the proportion of large fractions with a dispersion of $0.2-1.0 \mathrm{~mm}$ is from 26 to $50 \%$, fractions of $0.14-0.2 \mu \mathrm{m}$ - from 12 to $20 \%$, and the rest is accounted for fraction $0-0.14 \mu \mathrm{m}$, i.e. $37-60 \%$.
The granulometric analysis performed in the study allowed making the following conclusions.

Advantages:

1) availability of equipment and ease of use;

2) the possibility of obtaining the result only with help of a set of sieves, i.e. manually;

3 ) dry and wet granulometric analysis.

Disadvantages:

1) a qualitative dispersion analysis is impossible, sieving for certain fractions is only possible;

2) granulometric analysis by a dry method is applicable only for fractions with a dispersion of 63 microns, carrying out a granulometric analysis by the method of dry screening with a dispersion of less than 63 becomes inexpedient in terms of labor costs and reliability of the results obtained.

The fourth place in terms of largest number of solved problems is taken by laser diffraction analysis, which was performed with the help of the Malvern Mastersizer 2000 laser diffraction analyzer and software made for it. The fraction with dispersion of $0-200 \mu \mathrm{m}$ was the first subject to laser diffraction analysis. Then a sieve granulometric analysis was performed with obtaied fractions 0-45, 45-63, 63-94, 94-125, 125-140 and 140-200 microns. Each fraction was analyzed separately. The results are presentedin Fig. 8.

The method implemented with help of Mastersizer 2000 is necessary at the stage of testing the modes of the sieve granulometric analysis. It serves as a kind of passport for the quality of sieve screening of the sample. With help of that it is necessary to determine the maximum mass of the sample to be sieved and select the optimal mode of operation of the sieve analyzer. In the first case, this will reduce the amount of fine fractions. In the second case it 
reduces the number of reoriented larger particles that have slipped through the holes of the screenand in the second case if the vibrator and shock forces of the analyzer are properly selected.

Based on the experience of work at the Malvern Mastersizer 2000 following conclusions can be made.
Advantages:

1) any researcher can master the work on the equipment, i.e. we note the extreme simplicity of the operations necessary for performing the analysis;

2) highly informative and reliable method, since not single particles are studied, but the volume of a sample in which such particles can be more than $10^{12}$ pieces.;

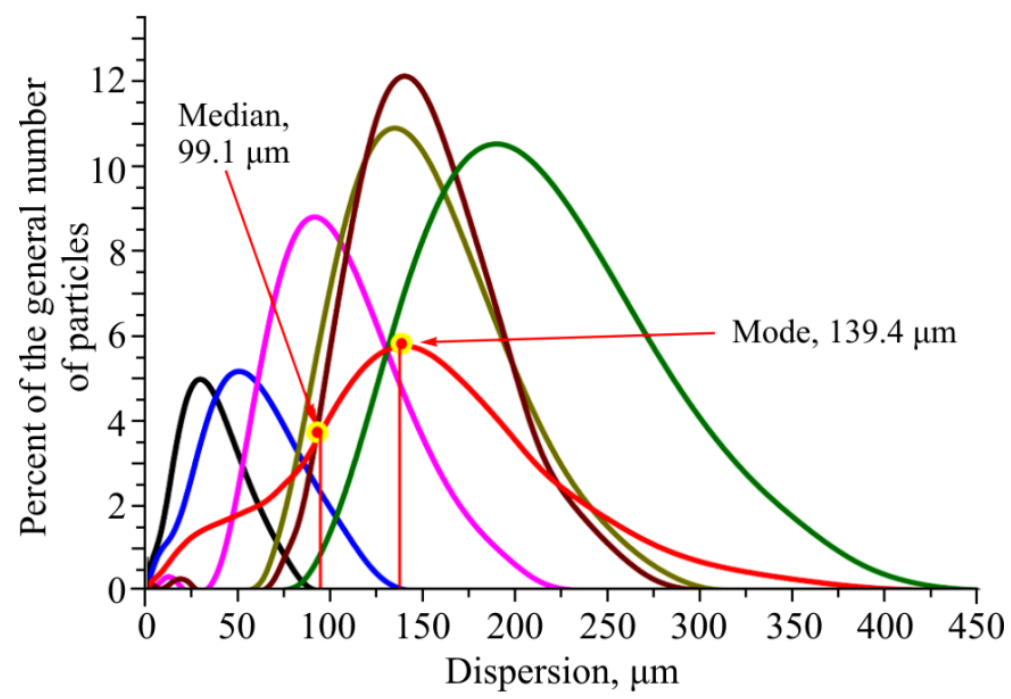

Fraction dispersion, $\mu \mathrm{m}$

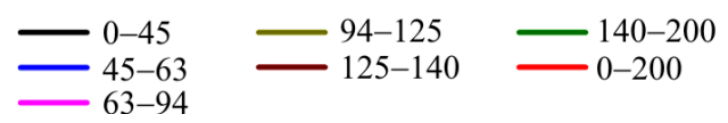

Fig. 8. Graphical display of results of analysis of anthracite coal dust, performed using the Malvern Mastersizer 2000

3) dry and sol (particles in an water medium) matter analysis. Application of "wet" analysis is especially important when studying the dispersion composition of mine or coal dust fractions with a size of less than $63 \mu \mathrm{m}$;

4) the simplest way to assess the quality and drill the methodology for implementation of a sieve granulometric analysis, which allows to reduce the labor costs for carrying out the dispersion analysis of dust particles significantly, in comparison with the microscopic study method.

Drawbacks of the method are as follows: it can be used to study only the dispersion composition of particles (size), and therefore it servs as an alternative method for determining the dispersion composition. A granulometric analysis can be used as a control method for particle size analysis.

For each of the analysis methods discussed above, there is a technique described in the equipment operation manual, but the initial stage of the determination of dispersion and other characteristics of mine (coal-rock) hard coal dust for all methods is the same.

Initial stage of any research work is sampling and sample preparation. 
Extraction of mine dust samples was carried out according to the recommendations set forth in [23], in particular from the surfaces of hydraulic stands of mechanical longwall support. Taken samples were loaded on site (in the working space of a longwall) in sealed containers. After a container was closed, the contact with the external environment is impossible, i.e. there is no access of air inside the container. Sample preparation included an external examination of the sample after opening the container, drying in an autoclave to an equilibrium state and sieve sieving. Samples passed through a sieve with a hole diameter of 1 $\mathrm{mm}$ were analized. Since in our case it was not necessary, the samples were not sieved when conducting studies with a scanning electron microscope.

\section{Conclusions}

1. Base on the research work carried out with help of various methods of studying the dispersion composition of mine dust of scientific research, we believe that the compilation of two mutually complementary methods should be based on the methodology for the comprehensive study of mine dust. In our opinion, such pairs can be presented by:

- laser diffraction analysis + microscopic method of investigation; in this case both the dispersed composition and structure of grains are reliably studied;

- sieve granulometric method + microscopic study method. The combination of these methods, just like in the previous case, will allow to comprehensively study mine dust. The difference between them is only in a larger number of operations to obtain reliable information (up to 250 images may be analyzed), i.e. labor intensity.

2. Studies of the dispersion composition of dust showed that in order to prevent and control both the occurrence of endogenous foci and explosions of methane-coal aerosol dispersions, in addition to methods for studying the dispersion composition and properties of mine dust, an integrated approach should be used. Such the approach as compilation of possibilities of disperse analysis and synchronous thermal analysis allows to answer the questions of chemical kinetics and thermodynamics (responsible for combustion and explosion processes that arise, including the space of coal mines).

\section{Reference}

1. Kolesnichenko I.E., Artem'ev V.B., Kolesnichenko E.A., Liubomishchenko E.I. Metanopylevaia opasnost' rudnichnoi atmosfery [Hazardous methane-dust mine atmosphere]. Ugol', 2017, no.9, pp.26-31. DOI: 10.18796/0041-5790-2017-9-26-31.

\section{Baranova A.S., Okhrimenko A.E.,} Stoliarova A.P., Stenina N.A. Analiz problem ugol'noi otrasli [Analysis of the problems of the coal industry]. Rossiia molodaia: IX
Vserossiiskoi nauchno-prakticheskoi konferentsii molodykh uchenykh, available at: http:// science.kuzstu.ru/wp-content/Events/Conference/RM/2017/RM17/index.htm (accessed 28 October 2017).

\section{Kulakov G.I. Avarii, sviazannye s} gazodinamicheskimi proiavleniiami na shakhtakh, i uroven' kvalifikatsii ITR ugol'nykh shakht Kuzbassa [Mine accidents related to gas-dynamic manifestations and the engineering personnel skill 
level at Kuzbass coal mines]. Interekspo GeoSibir', 2013, vol.2, no.3, pp.104-109.

4. Tolchenkin Iu.A., Chekvetadze F.A., Razumniak N.L. Rol' perepodgotovki rukovoditelei i spetsialistov $\mathrm{V}$ povyshenii promyshlennoi bezopasnosti na shakhtakh otrasli [Role of retraining of heads and experts in increase of industrial safety on mines of branch]. Ugol', 2007, no.10, pp.41-44.

5. Stas' G.V., Sheinkman L.E., Smirnova E.V. Risk vozniknoveniia avarii pri vozobnovlenii dobychi burykh uglei $\mathrm{v}$ podmoskovnom basseine [Evaluating risk of arising accidents by underground mining brown coal]. Izvestiia Izvestiia Tul'skogo gosudarstvennogo universiteta. Nauki o Zemle, 2016, iss.1, pp.61-71.

6. Vozdvizhenskaia A. Prichina ne za gorami. Smertnost' na ugol'nykh shakhtakh v nashei strane vyrosla vdvoe [The reason is not far away. Mortality in coal mines in our country doubled]. Rossiiskaia gazeta, federal'nyi vypusk no.7208 (42), available at: https://rg.ru/ 2017/02/28/smertnost-na-ugolnyhshahtah-v-rossii- vyrosla-vdvoe.html (accessed 04 December 2017).

7. Litvinov A.R., Kolikov K.S., Ishkhneli O.G. Avariinost' i travmatizm na predpriiatiiakh ugol'noi promyshlennosti v 2010-2015 godakh [Accident and injury at coal industry enterprises in 20102015]. Vestnik Nauchnogo tsentra, 2017, no.2, pp.6-17.

8. Shalaev V.S., Shalaev Iu.V., Liakhovskii G.V., Floria N.F. O normativnoi baze po vzryvozashchite gornykh vyrabotok ugol'nykh shakht [On normative base for explosion protection of coal mine workings].
Ugol', 2016, no.7 pp.34-37. DOI: 10.18796/0041-5790-2016-7-34-37

9. Artem'ev V.B., Lisovskii V.V., Galkin V.A., Kravchuk I.L. K sushchestvennomu povysheniiu bezopasnosti proizvodstva na predpriiatiiakh "SUEK" (ot "Karty boia" k "Ustavu boia" s opasnymi proizvodstvennymi situatsiiami) [Towards essential labor safety enhancement in "SUEK" enterprises (from the "Rattle planning map" to the hazardous production events "Rattle Charter")]. Ugol', 2016, 9. DOI: 10.18796/0041-5790-2016-9-4-9

10. Dzhigrin A.V., Isaev I.R., Miasnikov S.V. Prognozirovanie vzryvov gaza i pyli v ugol'nykh shakhtakh [Forecasting gas and dust explosions in coal mines]. Bezopasnost' truda v promyshlennosti, 2010, no.4, pp.38-42.

11. Khoroshilova L.S., Tarakanov A.V., Khoroshilov A.V. Prichiny vzryvov metana i ugol'noi pyli $\mathrm{v}$ shakhtakh Kuzbassa [Reasons of methane and coal dust explosions in Kuzbass mines]. Vestnik Nauchnogo tsentra, 2012, no.2, pp.187-191.

12. Dzhigrin A.V., Isaev I.R., Miasnikov S.V. Otsenka i prognozirovanie vzryvoopasnykh situatsii v gornykh vyrabotkakh ugol'nykh shakht [Estimation and prediction of explosive situations in mine workings of coal mines]. Natsional'nyi nauchnyi tsentr gornogo proizvodstva - Institut gornogo dela im. A.A. Skochinskogo. Moscow, 2010, iss.336: Problemy razrabotki ugol'nykh mestorozhdenii, p.101-110.

13. Kolesnichenko E.A., Artem'ev V.B., Kolesnichenko I.E., Liubomishchenko E.I. Energeticheskie i khimicheskie zakonomernosti vzryvov ugol'noi pyli v shakhtakh [Energy and chemical characteristics of explosions of coal dust 
in mine]. Gornaia promyshlennost', 2012, no.1, pp.24-30.

14. Mokhnachuk I.I. Problemy bezopasnosti na ugle dobyvaiushchikh predpriiatiiakh [Security on coal production enterprises]. Ugol', 2008, no.2, pp.21-26.

15. Romanchenko S.B. Samodispergatsiia ugol'noi pyli - printsipial'no novyi effekt, vyiavlennyi metodom lazernykh issledovanii [Selfdispersion of coal dust is a fundamentally new effect, revealed by the method of laser studies]. Gornyi informatsionno-analiticheskii biulleten' (nauchno-tekhnicheskii zhurnal), 2011, no.7, pp.378-385.

16. Khludov D.S., Olennikov S.V., Musinov S.N., Nevedrov A.V., Subbotin S.P. K voprosu o metodike opredeleniia uchastiia ugol'noi pyli vo vzryve metanovozdushnoi smesi [On the method of determining the participation of coal dust in a methane-air mixture explosion]. Vestnik Nauchnogo tsentra, 2014, no.2, pp.150-155.

17. Liliana Medich Peich, Khav'er Garsiia Torrent, Nievez Fernandez An'ez, Khorze Martin Molina Eskobar. Predotvrashchenie rasprostraneniia vzryvov metana i pyli v ugol'nykh shakhtakh [Prevention of the spread of methane and dust explosions in coal mines]. Zapiski Gornogo instituta, 2017, vol.225, pp.307-312. DOI: 10.18454/PMI.2017.3.307

18. Chunmiao Y., Chang L., Gang L. Coal dust explosion prevention and protection based on inherent safety. Journal Procedia Engineering, 2011, vol.26, pp.1517-1525. DOI: 10.1016/j.proeng.2011.11.2333

19. Technology news 515 - float coal dust explosion hazards. Technology news. NIOSH Publication No. 2006-125, Mining Safety and Health,
National Institute for Occupational Safety and Health, CDC, available at: https://www.cdc.gov/ niosh/mining/UserFiles/works/pdfs/2006-125.pdf (accessed 04 December 2017).

20. Ob utverzhdenii Federal'nykh norm i pravil v oblasti promyshlennoi bezopasnosti "Instruktsiia po lokalizatsii i preduprezhdeniiu vzryvov pylegazovozdushnykh smesei v ugol'nykh shakhtakh" [On the Approval of Federal Standarts and Rules in the Field of Industrial Safety "Instruction on the Localization and Prevention of Explosions of Dust-and-Air Mixtures in Coal Mines"]. Prikaz Rostekhnadzora ot 6 noiabria 2012 goda no.634, available at: http://docs.cntd.ru/ document/902381011 (accessed 04 December 2017).

21. Ob utverzhdenii Federal'nykh norm i pravil v oblasti promyshlennoi bezopasnosti "Instruktsiia po bor'be s pyl'iu v ugol'nykh shakhtakh" [On the Approval of Federal Standarts and Regulations in the Field of Industrial Safety "Regulations for Combating Dust in Coal Mines"]. Prikaz Rostekhnadzora ot 14.10.2014 no.462, available at: http:// minjust.consultant.ru/files/12732 (accessed 04 December 2017).

22. Iskhakov Kh.A., Schastlivtsev E.L., Kondratenko Iu.A. Vydelenie pyli iz riadovykh uglei [Dust extraction from ordinary coals]. Gornyi informatsionno-analiticheskii biulleten' (nauchnotekhnicheskii zhurnal), 2009, no.12, pp. 194-198

23. Romanchenko S.B., Rudenko Iu.F., Kosterenko V.N. Pylevaia dinamika v ugol'nykh shakhtakh [Dust dynamics in coal mines]. Moscow, Gornoe delo, 2011, 255 p.

24. Romanchenko S.B. Kompleksnye issledovaniia fraktsionnogo sostava ugol'noi pyli [Complex investigations of the fractional 
composition of coal dust]. Gornyi informatsionnoanaliticheskii biulleten' (nauchno-tekhnicheskii zhurnal), 2010, no.12, pp.128-142.

25. Particle size analysis: 6 methods used for particle size distribution, available at: https://www.studyread.com/particle-size-analysis (accessed 04 November 2017).

26. Particle size analysis John N. Staniforth and Kevin M.G. Taylor, available at: https://clinicalgate.com/particle-size-analysis/\# S0105 (accessed 04 November 2017).

27. Ajit Jillavenkatesa, Stanley J. Dapkunas, Lin-Sien H. Lum. Particle size characterization, available at: http://www.horiba.com/ fileadmin/ uploads/Scientific /Documents/PSA/NIST_SP9 601.pdf (accessed 04 November 2017).

28. Yueze L et al. Prediction of air flow, methane, and coal dust dispersion in a room and pillar mining face. Int J Min Sci Technol, 2017, DOI: 10.1016/j.ijmst.2017.05.019

29. Occupational safety and health guideline for coal dust (Less than 5 percnet $\mathrm{SiO}(2)$ ). Occupational Safety \& Health Administration, U.S. Department of Labor, available at: https://www.gpo.gov/fdsys/pkg/CFR-2007-title29vol6/pdf/CFR-2007-title29-vol6-sec1910-1001.pdf (accesed 20 August 2017).

30. Gwo S., Smith A.R., Chao K.-J.,. Shih C.K, Sadra K., Streetman B.G. Crosssectional scanning tunneling microscopy and spectroscopy of passivated III-V heterostructures. Journal Vacuum Science and Technology, 1994, vol.A12, no.4, pp.2005-2008. DOI: $10.1116 / 1.578997$

31. Kremenev O.G. Dispersnyi sostav pyli $\mathrm{v}$ atmosfere vozdukhopodaiushchikh i ventiliatsionnykh vyrabotok ugol'noi shakhty
[Disperse composition of dust in the atmosphere the air supply and ventilation of mine workings in coal mines]. Vestnik Nauchnogo tsentra, 2016, no.3, pp.110-117.

32. Rogalis V.S., Pavlenko M.V., Shilov A.A. Sochetanie vozdeistviia ugol'noi pyli i radiatsii na zdorov'e shakhterov [The combination of exposure to coal dust and radiation on the health of miners]. Gornyi informatsionno-analiticheskii biulleten' (nauchno-tekhnicheskii zhurnal), 2016, no.3, pp.109-120.

33. Colinet J.F., Rider J.P., Listak J.M., Organiscak J.A., Wolfe A.L. Best practices for dust control in coal mining. Information Circular 9517, DHHS (NIOSH) Publication No. 2010-110, available at: https://www.cdc.gov/niosh/mining/ UserFiles/works/pdfs/2010-110.pdf (accesed 20 August 2017).

34. Sapko M.J., Weiss E.S., Cashdollar K.L., Zlochower I.A. Experimental mine and laboratory dus $\mathrm{t}$ explosion research at NIOSH. Journal of Loss Prevention in the Process Industries, 2000, vol.13, iss.3-5, pp.229-242. DOI: 10.1016/S0950-4230(99)00038-8

35. Shuai $\mathrm{Wu}$, Sheng-qiang Yang, Jian-Bo Wang, Jie Liu. Applied study on dust reduction and control technology with high pressure air jet spray. Journal of Coal Engineering, 2011, 43(4), pp.64-66.

36. Plessis du J.J.L. Active explosion barrier performance against methane and coal dust explosions. Int J Coal Sci Technol, 2015, 2(4), pp.261-268, DOI:10/1007/s40789-015-0097-7

37. Ratnesh Trivedi, Chakraborty M.K., Tewary B.K. Dust dispersion modeling using fugitive dust model at an opencast coal project of Western Coalfields Limited, India. Journal of 
Scientific \& Industrial Research, 2009, vol.68, pp.71-78.

38. Weiguoa Cao, Liyuana Huang, Jianxinb Zhang, Sen Xu, Shanshana Qiu, Feng Pan. Research on characteristic parameters of coal dust explosion. Procedia Engineering, 2012, vol.45, pp.442-447. DOI: $10.1016 /$ j.proeng.2012.08.183
39. Igishev V.G., Shlapakov P.A., Khaimin S.A., Sin S.A. Vydelenie indikatornykh pozharnykh gazov pri okislenii uglia na stadiiakh samonagrevaniia i besplamennogo goreniia [Fire indicator gases liberation at coal oxidation at the stage of self-heating and flameless combustio]. Vestnik Nauchnogo tsentra, 2015, no.4, pp.55-59.

\section{Библиографический список}

1. Метанопылевая опасность рудничной атмосферы / И.Е. Колесниченко, В.Б. Артемьев, Е.А. Колесниченко, Е.И. Любомищенко // Уголь. - 2017. - № 9. - C. 26-31. DOI: 10.18796/0041-5790-2017-9-26-31.

2. Анализ проблем угольной отрасли / А.С. Баранова, А.Е. Охрименко, А.П. Столярова, Н.А. Стенина [Электронный ресурс] // Россия молодая: IX Bсерос. науч.-практ. конф. молодых ученых, 18-21 апреля 2017 г. URL: http://science.kuzstu.ru/wp-content/Events/ Conference/RM/2017/RM17/index.htm (дата обращения: 28.10.2017).

3. Кулаков Г.И. Аварии, связанные с газодинамическими проявлениями на шахтах, и уровень квалификации ИТР угольных шахт Кузбасса // Интерэкспо Гео-Сибирь. - 2013. Т. 2, № 3. - С. 104-109.

4. Толченкин Ю.А., Чекветадзе Ф.А., Разумняк Н.Л. Роль переподготовки руководителей и специалистов в повышении промышленной безопасности на шахтах отрасли // Уголь. - 2007. № 10. - C. 41-44.

5. Стась Г.В., Шейнкман Л.Э., Смирнова Е.В. Риск возникновения аварий при возобновлении добычи бурых углей в подмосковном бассейне // Известия
Тульского государственного университета. Науки о Земле. - 2016. - Вып. 1. C. 61-71.

6. Воздвиженская А. Причина не за горами. Смертность на угольных шахтах в нашей стране выросла вдвое // Российская газета - Федеральный выпуск № 7208 (42) [Электронный pecypc]. - https://rg.ru/ 2017/ 02/28/smertnost-na-ugolnyh-shahtah-vrossii-vyrosla-vdvoe.html (дата обращения: 04.12.2017).

7. Литвинов А.Р., Коликов К.С., Ишхнели О.Г. Аварийность и травматизм на предприятиях угольной промышленности в 2010-2015 годах // Вестник научного центра. - 2017. - № 2. C. 6-17.

8. О нормативной базе по взрывозащите горных выработок угольных шахт / В.С. Шалаев, Ю.В. Шалаев, Г.В. Ляховский, Н.Ф. Флоря // Уголь. - 2016. - № 7. - С. 34-37. DOI: 10.18796/0041-5790-2016-7-34-37

9. К существенному повышению безопасности производства на предприятиях «СУЭК» (от «Карты боя» - к «Уставу боя» с опасными производственными ситуациями) / В.Б. Артемьев, В.В. Лисовский, В.А. Галкин, И.Л. Кравчук // Уголь. - 2016. - 9. DOI: 10.18796/0041-5790-2016-9-4-9 
10. Джигрин А.В., Исаев И.Р., Мясников С.В. Прогнозирование взрывов газа и пыли в угольных шахтах // Безопасность труда в промышленности. - 2010. - № 4. C. $38-42$.

11. Хорошилова Л.С., Тараканов А.В., Хорошилов А.В. Причины взрывов метана и угольной пыли в шахтах Кузбасса // Вестник научного центра. - 2012. - № 2. C. 187-191.

12. Джигрин А.В., Исаев И.Р., Мясников С.В. Оценка и прогнозирование взрывоопасных ситуаций в горных выработках угольных шахт / Нац. науч. центр горн. пр-ва - Ин-т горн. дела им. А.А. Скочинского. - М., 2010. Вып. 336: Проблемы разработки угольных месторождений. - С. 101-110.

13. Энергетические и химические закономерности взрывов угольной пыли в шахтах / Е.А. Колесниченко, В.Б. Артемьев, И.Е. Колесниченко, Е.И. Любомищенко // Горная промышленность. - 2012. - № 1. C. 24-30.

14. Мохначук И.И. Проблемы безопасности на угле добывающих предприятиях // Уголь. 2008. - № 2. - С. 21-26.

15. Романченко С.Б. Самодиспергация угольной пыли - принципиально новый эффект, выявленный методом лазерных исследований // Горный информационноаналитический бюллетень (научно-технический журнал. - 2011. - № 7. - С. 378-385.

16. К вопросу о методике определения участия угольной пыли во взрыве метановоздушной смеси / Д.С. Хлудов, С.В. Оленников, С.Н. Мусинов, А.В. Неведров, С.П. Субботин // Вестник научного центра. 2014. - № 2. - C. 150-155.
17. Предотвращение распространения взрывов метана и пыли в угольных шахтах / Лилиана Медич Пейч, Хавьер Гарсия Торрент, Ниевез Фернандез Аньез, Хорзе Мартин Молина Эскобар // Записки Горного института. - 2017. - Т. 225. - С. 307-312. DOI: 10.18454/PMI.2017.3.307

18. Chunmiao Y., Chang L., Gang L. Coal dust explosion prevention and protection based on inherent safety // Journal Procedia Engineering. 2011. - Vol. 26. - P. 1517-1525. DOI: 10.1016/j.proeng.2011.11.2333

19. Technology news 515 - float coal dust explosion hazards [Электронный pecypc]. - URL: https://www.cdc.gov/niosh/mining/UserFiles/ works/pdfs/2006-125.pdf (дата обращения: 04.12.2017).

20. Об утверждении Федеральных норм и правил в области промышленной безопасности «Инструкция по локализации и предупреждению взрывов пылегазовоздушных смесей в угольных шахтах»: Приказ Ростехнадзора от 6 ноября 2012 года № 634 (с изменениями на 22 июня 2016 года) [Электронный pecypc]. - URL: http://docs.cntd.ru/document/902381011 (дата обращения: 04.12.2017).

21. Об утверждении Федеральных норм и правил в области промышленной безопасности «Инструкция по борьбе с пылью в угольных шахтах»: Приказ Ростехнадзора от 14.10.2014 № 462 [Электронный peсурс]. - URL: http:// minjust.consultant.ru/files/12732 (дата обращения: 04.12.2017).

22. Исхаков Х.А., Счастливцев Е.Л., Кондратенко Ю.А. Выделение пыли из рядовых углей // Горный информационноаналитический бюллетень (научно-техни- 
ческий журнал). - 2009. - № 12 . С. 194-198.

23. Романченко С.Б., Руденко Ю.Ф., Костеренко В.Н. Пылевая динамика в угольных шахтах. - М.: Горное дело, 2011. - 255 с.

24. Романченко С.Б. Комплексные исследования фракционного состава угольной пыли // Горный информационно-аналитический бюллетень (научно-технический журнал). 2010. - № 12. - C. 128-142.

25. Particle size analysis: 6 methods used for particle size distribution [Электронный ресурс]. URL: https://www.studyread.com/particle-sizeanalysis (дата обращения: 04.11.2017).

26. Particle size analysis John N. Staniforth and Kevin M.G. Taylor [Электронный pecypc]. URL: https://clinicalgate.com/particle-size-analysis/\#S0105 (дата обращения: 04.11.2017).

27. Ajit Jillavenkatesa, Stanley J. Dapkunas, Lin-Sien H. Lum. Particle size characterization // Materials Science and Engineering Laboratory. NIST Recommended Practice Guide [Электронный pecypc]. - URL: http://www.horiba.com/fileadmin/uploads/Scienti fic/Documents/PSA/NIST_SP9601.pdf (дата обращения: 04.11.2017).

28. Yueze L et al. Prediction of air flow, methane, and coal dust dispersion in a room and pillar mining face // Int J Min Sci Technol. - 2017. DOI: 10.1016/j.ijmst.2017.05.019

29. Occupational safety and health guideline for coal dust (Less than 5 percnet $\mathrm{SiO}(2)$ ). Occupational Safety \& Health Administration, U.S. Department of Labor [Электронный pecypc]. - URL: https://www.gpo.gov/fdsys/ pkg/CFR-2007-title29-vol6/pdf/CFR-2007-title29vol6-sec1910-1001.pdf (дата обращения 20.08.2017).
30. Cross-sectional scanning tunneling microscopy and spectroscopy of passivated III-V heterostructures / S. Gwo, A.R. Smith, K.-J. Chao, C.K. Shih, K. Sadra, B.G. Streetman // Journal Vacuum Science and Technology. - 1994. Vol. A12, № 4. - P. 2005-2008. DOI: $10.1116 / 1.578997$

31. Кременев О.Г. Дисперсный состав пыли в атмосфере воздухоподающих и вентиляционных выработок угольной шахты // Вестник Научного центра. - 2016. - № 3. C. $110-117$.

32. Рогалис В.С., Павленко М.В., Шилов А.А. Сочетание воздействия угольной пыли и радиации на здоровье шахтеров // Горный информационно-аналитический бюллетень (научно-технический журнал). - 2016. - № 3. C. $109-120$.

33. Best practices for dust control in coal mining / J.F. Colinet, J.P. Rider, J.M. Listak, J.A. Organiscak, A.L. Wolfe // Information Circular 9517, DHHS (NIOSH) Publication No. 2010-110 [Электронный peсурс]. URL: $\quad$ https://www.cdc.gov/niosh/mining/User Files/works/pdfs/2010-110.pdf (дата обращения: 20.08.2017).

34. Experimental mine and laboratory dust explosion research at NIOSH / M.J. Sapko, E.S. Weiss, K.L. Cashdollar, I.A. Zlochower // Journal of Loss Prevention in the Process Industries. - 2000. - Vol. 13, iss. 3-5. - P. 229-242. DOI: 10.1016/S0950-4230(99)00038-8

35. Applied study on dust reduction and control technology with high pressure air jet spray / Shuai Wu, Sheng-qiang Yang, Jian-Bo Wang, Jie Liu // Journal of Coal Engineering. 2011. - 43(4). - P. 64-66. 
36. du Plessis J.J.L. Active explosion 38. Research on characteristic parameters of barrier performance against methane coal dust explosion / Weiguoa Cao, Liyuana and coal dust explosions // Int J Coal Sci Huang, Jianxinb Zhang, Sen Xu, Shanshana Qiu, Technol. - 2015. - 2(4). - P.261-268. Feng Pan // Procedia Engineering. - 2012. - Vol. 45. DOI:10/1007/s40789-015-0097-7 - P. 442-447. DOI: 10.1016/j.proeng.2012.08.183

37. Ratnesh Trivedi, Chakraborty M.K., 39. Выделение индикаторных пожарных Tewary B.K. Dust dispersion modeling using fugitive dust model at an opencast coal project of Western Coalfields Limited, India // Journal of газов при окислении угля на стадиях самонагревания и беспламенного горения / Scientific \& Industrial Research. - 2009. Vol. 68. - P. 71-78. В.Г. Игишев, П.А. Шлапаков, С.А. Хаймин, С.А. Син // Вестник Научного центра. - 2015. № 4. - С. 55-59.

Please cite this article in English as:

Rodionov V.A. Methodological bases of studying the dispersion composition of mine coal dust. Perm Journal of Petroleum and Mining Engineering, 2018, vol.17, no.1, pp.71-87. DOI: 10.15593/2224-9923/2018.1.7

Просьба ссылаться на эту статью в русскоязычных источниках следующим образом:

Родионов В.А. Методологические основы изучения дисперсионного состава шахтной каменноугольной пыли // Вестник Пермского национального исследовательского политехнического университета. Геология. Нефтегазовое и горное дело. 2018. - T.17, №1. - C.71-87. DOI: 10.15593/2224-9923/2018.1.7 